\title{
Personal and Academic Aspects that Contributed to the Development of the English Language Competence of Students from a Language Teacher Education Program
}

\author{
Leonardo Herrera-Mosquera $^{1} \&$ Alejandra Tovar-Perdomo ${ }^{1}$ \\ ${ }^{1}$ School of Education, Universidad Surcolombiana, Neiva, Colombia \\ Correspondence: Leonardo Herrera-Mosquera, Calle 41 No. 19-50 Casa 59, Condominio Villas del Prado, Neiva, \\ Colombia. Tel: 57-310-589-7902. E-mail: leonardo.herrera@usco.edu.co
}

Received: August 17, 2017 Accepted: September 13, 2017 Online Published: September 15, 2017

doi: 10.5539/elt.v10n10p140 URL: http://doi.org/10.5539/elt.v10n10p140

\begin{abstract}
Students from the English as a Foreign Language (EFL) Program targeted in the present study are expected to achieve a $\mathrm{C} 1$ level of English proficiency according to the Common European Framework (CEF). However, only a five per cent of the students has evidenced this level on the institutional English exam (Ileusco Test, henceforth IT) for the past five years. Through the present descriptive-exploratory qualitative study we have attempted to inquire about the personal and academic factors that may have contributed to the successful development of the L2 competence of those learners.

We used a questionnaire, individual interviews and focus-group interviews to ask 12 students about learning strategies, experiences and actions they have implemented to develop their 12 competence. We concluded that it is mainly students' commitment and self-discipline that helped them keep their L2 learning process successfully running; that despite the high quality of a school curriculum, a language program or a teaching methodology, it is students' autonomous learning initiatives that mainly enhance their L2 proficiency; and that L2 instruction in higher education seems to convey a stronger impact than elementary and secondary education.
\end{abstract}

Keywords: English as a Foreign Language (EFL), English language competence, English language proficiency, learning strategies, autonomous learning

\section{Introduction}

As English has become the language of communication and business around the world, many countries have recognized the relevance of promoting the learning of this language in all levels of education. Colombians are not the exception to this linguistic, academic, labor or cultural need and therefore, its Ministry of Education and Departments of Education have issued important educational policies that promote the learning of English as a foreign language. Thus, English as a school subject has received all the attention of educational policy makers as well as school administrators as part of different national and local bilingualism programs.

The National Bilingualism Program, created by the Colombian Ministry of Education in 2004, offers all students in the country the possibility of becoming bilingual in English and Spanish as part of a vision of increased productivity in a globalized world. For instance, the Secretary of Education of Huila launched a program called "Huila habla inglés" (Huila speaks English) where all public schools have to promote the use of this second language not only in English classes but also throughout cultural and extra-curricular events. At the higher education level, the only public university in the Department of Huila, Universidad Surcolombiana, follows ordinance 2450 and resolution 02041 , which state that any student from any undergraduate program belonging to the school of education, at the end of the program must have a B1 level in English according to the CEFR. Moreover, it requires a $\mathrm{C} 1$ level from any student who is studying a Language Teacher Education program. Based on what it is required, it is essential to know how the results on the IT have served as evidence of the level of English proficiency developed by the students from the teacher education program. Over the past five years of implementation of the IT, only $5 \%$ of the test takers have reached the expected level (C1). In other words, there is a high $95 \%$ of students who have not yet reached the expected level stated by the new law. This is a very significant percentage for a program that has been repeatedly acknowledged as a high-quality academic program by the National Ministry of Education. 
The IT results made us wonder why this learning process worked only for a few students and what learning strategies they might have used in order to become successful learners. We also wondered if there were other factors that influenced positively the learning of this reduced group. Since a previous research study conducted within the program (Rojas and Artunduaga, 2014) inquired on the reasons why some students did not reach the expected level of L2 proficiency, we decided instead to inquire on the factors that contributed to the success of that reduced $5 \%$ of students who were obtaining a $\mathrm{C} 1$ score on the IT. It is important to highlight that these students were also outstanding students throughout the L2 courses in the program.

Thus, these reflections led us to conduct a research study that tapped into the following question: What personal and academic aspects have influenced positively students' English language competence in a foreign language teacher education program at a Colombian university?

With the purpose of answering this research question, we stated the following specific objectives that may help us guide the study: a) to identify meaningful experiences that helped students to have an effective performance in English classes during the program and reach a $\mathrm{C} 1$ level on the Ileusco test; $\mathrm{b}$ ) to recognize the academic practices that help students not only to obtain the highest level on the Ileusco Test but also an outstanding performance in the English courses throughout the program; c) to define the aspects related to learning strategies that have an impact on the students' results of the Ileusco test and their performance in the English courses; and d) to recommend learning strategies and actions that language students can implement in order to become successful learners.

\section{Literature Review}

In order to identify the diverse factors that impact learners or the learning process, it is paramount to review some theoretical constructs that may shed light on the analysis of the phenomenon targeted in the present study. Some of the constructs reviewed hereinafter are diversity in learning and learners, learning strategies, and motivation for learning an L2. Additionally, five similar studies have been reviewed towards the end of the section.

\subsection{Diversity in Learning and Learners}

Every language learner goes through different circumstances or exhibit different abilities throughout their learning process, yet sometimes those are taken for granted or ignored. Saville-Troike (2006) states that what is learnt in acquiring a second language as well as how it is learnt is usually influenced by the situation where this process takes place. Besides, these learning conditions can be affected by social, cultural and economic factors which have an impact on the status of the language and the learners. As Saville-Troike (2006) states,

The intriguing question of why some L2 learners are more successful than others requires us to unpack the broad label "learners" for some dimensions of discussion (...) there are different factors which may be categorized in these dimensions and seen from different perspectives (p. 5).

In the linguistic field, the categories can be determined, according to Saville-Troike (2006), by the relationship of their L1 and L2; psycholinguistics may talk about the differences on "individual aptitude for L2 learning, personality factors, types and strength of motivation and learning strategies"; and sociolinguistics may relate "the social, economic and political differences and learner experiences in negotiated interaction" (p. 5).

From a psychological perspective, there are three aspects to take into account: Languages and the brain, learning processes and learner differences. Lenneberg (as cited in Saville-Troike, 2006) argued that there is a critical period for language acquisition which has a neurological basis; learning processes have been influenced by computer based information, processability and connectionism. The focus on learner differences in Second language acquisition is based on the question of why some learners are more successful than others. It takes into consideration the emotional involvement in learning, such as affective attitude factors, motivation and anxiety level. This focus also considers biological differences associated with age and gender and some aspects of processing (Saville-Troike, 2006).

\subsection{Styles and Strategies for Learning a Second Language}

There are different factors that influence every student's ability to learn an L2 in a particular way. It depends on some specific behaviors, strategies and thoughts learners implement to strengthen their knowledge of this second language. Language learning styles and strategies constitute factors that help determine how a student is going to learn the language. Learning styles, on one hand, are defined as the general paths that students use for acquiring an L2; these styles are a set of characteristics which help the students have a greater knowledge of the new language. According to Oxford ((2003), not all students have the same sensory preferences, which are the perceptual learning channels that a student is more comfortable with. Some students are more visual and prefer 
to read and get information from visual stimulation. For them, receiving directions and keeping conversations without visual backup can be very confusing. On the other hand, auditory students do not have a problem with oral instructions and prefer to take part in role-plays and similar activities. In some cases, auditory students have difficulties with physical activities. Kinesthetic students prefer activities that involve movement and do not like to stay still for a long period of time.

Furthermore, the learning styles of a student can also depend on biological factors such as their biological clock, nutrition and location. Some L2 learners are morning people, which makes them feel and perform better in the morning; other learners prefer to learn in the afternoon and others prefer night. This is where their biological clock may influence the learning style. When it comes to nutrition, some learners feel the need of eating or drinking something while learning and others are just distracted by food. The same phenomenon occurs with aspects that involve the environment such as temperature, lighting or sound (Oxford, 2003).

Learning strategies, on the other hand, are defined as "specific actions, behaviors, steps, or techniques that students (often intentionally) use to improve their progress in developing second language skills" (Ghani, 2003, as cited in Hardn, 2013). Cohen (2011) defines strategies as "thoughts and actions, consciously chosen and operationalized by language learners, to assist them in carrying out a multiplicity of tasks from the very onset of learning to the most advanced levels of target-language performance" (p. 7). These strategies can become useful for an active, conscious and purposeful control of learning. For a strategy to be helpful for a learner it must present a set of conditions; for example, when it is related to the given task, when it fits the learners' style preferences and if the student applies the strategy effectively. If the strategies used meet the conditions mentioned, it "makes learning easier, faster, more enjoyable, more self-directed, more effective, and more transferable to new situations" (Oxford, 1990, p. 8, as cited in Oxford, 2003).

There are many positive outcomes when using strategies and it is highly related to achievement and proficiency in the L2 of a student. According to Naiman, Fröhlich, Stern, and Todesco, (1975, as cited in Oxford, 2003) "good learners" are those who consistently used certain types of learning strategies and that there is not a single set of learning strategies used by "good learners." Strategies can also help students become more autonomous and independent, yet not all are aware of the advantages of using strategies as means for learning an L2.

\subsection{Motivation for L2 Learning}

In the process of acquiring an L2, the extent of the learners' competence and proficiency depends mainly on the motivation he or she has towards learning the language. "It is difficult to imagine anyone learning a language without some degree of motivation" (Hall, 2011, p. 134). Motivation is the one who determines the way a person is going to behave; in other words, "motivation is the choice of an action, it is responsible for being the reason why people decide to do something, how long they are willing to sustain the activity, and how hard they are going to pursue it" (Dörnyei, 2009, p. 519). Loewen and Reinders (2011) define motivation as "a psychological construct that refers to the desire and incentive that an individual has to engage in a specific activity" (p. 119).

Gardner and Lambert (as cited in Dörnyei, 2009) mention two types of motivation that language learners typically have. One of them is instrumental motivation, in which learning the L2 becomes a tool that will allow the student to achieve a goal, such as getting a job or a bigger salary (Gardner \& Lambert, as cited in Dörnyei, 2009). The second type relates to the integrative motivation. Students who have this type of motivation want to learn the language to interact and communicate with native speakers and get to know the culture of the associated language. It is more likely that integrative motivated learners are more successful than those who have instrumental motivation because their motivation is stronger.

Several studies have been conducted on second language learning strategies; in which some factors have been pointed out that might affect language learning strategies. Additionally, these studies mention the close relationship between learning strategies and the language proficiency of learners.

A study conducted by García-Ros, Pérez-González, Martínez, and Alfonso (1998) determined the learning strategies valued by secondary school students learning English as a second language. It analyzed the relationship between the motivational variable and the academic achievement in this curriculum area and detected the existence of differential patterns in the usefulness of strategies. They concluded that more valuable learning strategies in learning a Second Language are those that involve a degree of personalization of information which involves the modification of the basic characteristics of it; for example, summarizing and making a scheme. They also highlight social strategies in which they look for more skillful peers and work together with others to check their work along the way.

In a study conducted by García (2000) about training learning strategies in EFL context of blended learning, L2 
students were exposed to blended learning where they take classes with the guidance of a teacher and using a communicative approach. The students were trained in using learning strategies with aims of finding more benefits in language learning. This study showed that second language students implemented learning strategies such as metacognitive strategies, cognitive, emotional and social strategies to deal with all the implications that language learning involves. Although the use of strategies is mostly a mental process, verbalization in the use of these (through daily writing in a logbook registration) allows students to become more aware of the benefits of using these types of strategies. Moreover, there is an explicit and clear direction that allows students to internalize the constant use of strategies as part of the learning process.

A recent research done by Ochoa, Cabrera, Quiñónez, Castillo and González (2016) shows the impact of communicative activities on students who learn English as a second language. A mixed-method approach was applied in this study with a sample population of 180 high school students. With questionnaires and interviews, the study depicted that students were motivated when they were able to interact with their peers in class activities such as discussions, games and group work. They were more motivated when they saw the teacher as a guide who helped them understand certain topics better and corrected them when they were wrong. Students felt that activities such as games, role plays and group work gave them the opportunity to use the language in a real context and most of all, in an enjoyable way (Ochoa, Cabrera, Quiñónez, Castillo, \& González, 2016).

Another related investigation was carried out at a bilingual North American-style college preparatory school located in Colombia, South America. The results of this study showed the benefits which an experiential education program has on students in the K-12 range. In 2009, Gama and Fernandez implemented a program called Classroom without Walls (CWW) whose objective was the experiential education at the school. They offered the program to students from kindergarten to tenth grade including one CWW trip once a year. After analyzing the information from surveys, testimonials and informal feedback, four themes emerged: the academic value of the trips, the student's area of emotional well-being, social interaction and development of physical skills and abilities. With these four themes, they were able to conclude that regarding the academic aspect students were satisfied. However, they noted that there must be a preparation stage in further applications where the staff are involved and the trips are more associated with the curriculum of the school.

Gómez and Pérez (2015) conducted a study titled "Chilean 12th graders' attitudes towards English as a foreign language" about how students feel English in the classroom, as a global language and learning English as a second language. The 154 participants answered a questionnaire which inquired about their demographic information, their attitude towards English in class, the teachers' methodology, English as a subject and their attitude towards English as an L2. The results showed that students had a positive attitude when it comes to English as an L2; they understood the importance of learning this L2 in the modern world. On the other hand, students preferred a more frequent use of their mother tongue when the teacher gave an instruction during the class. In regards to the attitude when it comes to learning English, students did not put in enough time and did not have study habits, which is a very important factor when learning an L2.

Reviewing the research studies held in the area of EFL learning, we find that there is still an area that needs further investigation. Research that aims at recognizing personal and academic aspects that have an impact on the successful development of the EFL competence of college-level students need to be carried out. For this reason, we have conducted the present study hoping to identify helpful factors and strategies for EFL learners.

\section{Method}

In order to answer the aforementioned research question, a descriptive-exploratory qualitative study was followed. Since qualitative research studies are inductive, they are evaluated based on the total absence of any sort of theory (Mitchell \& Cody as cited in Thomas, Nelson, \& Silverman, 2015) and as a result it helps the researcher construct a useful theory within research (Leedy \& Ormrod, as cited in Tavallaei, and Abu Talib, 2010; Creswell, 2009).

About the exploratory approach, this type of research is not intended to provide conclusive evidence, but to provide us with a better understanding of the problem. Exploratory research is the initial research, which forms the basis of more conclusive research. It can even help in determining the research design, sampling methodology and data collection method (Fraenkel, Wallen, \& Hyun, 2011).

\subsection{Sample}

This study used a purposeful sample. There was an established criterion to select the participants. It was those students who took the IT over the last five years in fourth or eighth semester of the EFL program at Colombian public university and obtained a C1 score. Students (current and graduates) were invited to participate via phone 
calls and emails where they kindly accepted to cooperate and signed a consent form. The sample was made up of 8 women and 4 men, whose ages ranged from 20 to 26 years old. Eight students are still enrolled in the program and four already graduated.

The following charts show numeric scores of the 12 students in both the IT and each of the English courses in the program. Chart 1 shows the score of each of the participants based on the criteria of the program when evaluating the IT, the different skills evaluated and the total score of the participants. Chart 2 shows their average scores (GPA) in the program and in each English course. This chart is presented in descending order according to the total Score in the IT.

Chart 1. Participants' IT scores

\begin{tabular}{|c|c|c|c|c|c|c|}
\hline Code & Speaking & Reading & Listening & Use of Eng & Writing & Total \\
\hline Student 10 & $34 \mathrm{C} 1$ & $28 \mathrm{C} 1$ & $27 \mathrm{C} 1$ & $18 \mathrm{C} 1$ & $32 \mathrm{C} 1$ & $139 \mathrm{C} 1$ \\
\hline Student 9 & $34 \mathrm{C} 1$ & $26 \mathrm{C} 1$ & $30 \mathrm{C} 1$ & $17 \mathrm{C} 1$ & $29 \mathrm{~B} 2$ & $136 \mathrm{C} 1$ \\
\hline Student 12 & $34 \mathrm{C} 1$ & $26 \mathrm{C} 1$ & $23 \mathrm{~B} 2$ & $18 \mathrm{C} 1$ & $32 \mathrm{C} 1$ & $133 \mathrm{C} 1$ \\
\hline Student 11 & $30 \mathrm{C} 1$ & $28 \mathrm{C} 1$ & $25,5 \mathrm{C} 1$ & $19 \mathrm{C} 1$ & $29 \mathrm{~B} 2$ & 131,5 \\
\hline Student 5 & $32,4 \mathrm{C} 1$ & $24 \mathrm{~B} 2$ & $27 \mathrm{C} 1$ & $19 \mathrm{C} 1$ & $28 \mathrm{~B} 2$ & $130,4 \mathrm{C} 1$ \\
\hline Student 2 & $32 \mathrm{C} 1$ & $26 \mathrm{C} 1$ & $25 \mathrm{~B} 2$ & $16 \mathrm{~B} 2$ & $31 \mathrm{C} 1$ & $130 \mathrm{C} 1$ \\
\hline Student 1 & $30,5 \mathrm{C} 1$ & $24 \mathrm{~B} 2$ & $25,5 \mathrm{C} 1$ & $17 \mathrm{C} 1$ & $33 \mathrm{C} 1$ & $130 \mathrm{C} 1$ \\
\hline Student 6 & $30,6 \mathrm{C} 1$ & $28 \mathrm{C} 1$ & $25,5 \mathrm{C} 1$ & $19 \mathrm{C} 1$ & $29 \mathrm{~B} 2$ & 129,6 \\
\hline Student 3 & $27 \mathrm{~B} 2$ & $24 \mathrm{~B} 2$ & $28,5 \mathrm{C} 1$ & 19 & $30 \mathrm{C} 1$ & 128,5 \\
\hline Student 4 & $30,2 \mathrm{CQ}$ & $28 \mathrm{C} 1$ & $25 \mathrm{~B} 2$ & $19 \mathrm{C} 1$ & 26 & 128,2 \\
\hline Student 8 & $28,5 \mathrm{~B} 2$ & $26 \mathrm{C} 1$ & $25,5 \mathrm{C} 1$ & $20 \mathrm{C} 1$ & 27,6 B2 & 127,6 \\
\hline Student 7 & 29 & 28 & 27,5 & 15 & 28 & 127,5 \\
\hline
\end{tabular}

Chart 2. Participants' GPA in English course

\begin{tabular}{lll}
\hline & ENGLISH COURSE GPA & PROGRAM GPA \\
\hline Student 1 & 4,2 & 4,4 \\
Student 2 & 4,5 & 4,36 \\
Student 3 & 3,7 & 3,1 \\
Student 4 & 4,3 & 4,07 \\
Student 5 & 4,6 & 4,51 \\
Student 6 & 3,3 & 4,04 \\
Student 7 & 4,3 & 3,87 \\
Student 8 & 3,8 & 4,08 \\
Student 9 & 4,4 & 4,05 \\
Student 10 & 4,4 & 4,24 \\
Student 11 & 4,3 & 4,43 \\
Student 12 & 4,5 & 4,49 \\
\hline
\end{tabular}

\subsection{Instruments}

The most common sources of data collection in qualitative research are interviews, observations, and review of documents, (Creswell, as cited in Tavallaei, \& Abu Talib, 2010; Locke, Silverman, and Spirduso; Marshall and Rossman as cited in Thomas, Nelson, \& Silverman, 2015) For the present study, we conducted a questionnaire as well as individual and group interviews.

Questionnaire: This was the first instrument the participants answered. It had 19 closed questions about their personal and academic experiences and one open-ended question about the strategies they thought have helped them acquire a $\mathrm{C} 1$ level throughout their college program. The questionnaire was sent via e-mail to all the participants and they were given one week to answer it online. 
Individual interviews: After obtaining a general view on the aspects mentioned in the previous instrument, we selected the most common relevant facts among participants. These aspects were discussed in individual interviews where the participants provided us with further information that led us to answer the research question. The interview was semi-structured and based on a list of questions and topics that complemented those included in the initial questionnaire.

Focus group interview: This was a semi- structured interview which had a set of prepared questions based on the two previous instruments. The aspects discussed in this group interview needed to be extended with all participants together to dig deeply on their opinions. The focus group interview was scheduled at night so the majority of participants could attend.

Analysis of artifacts: In order to have more information about the population sample, we analyzed the academic performance of the participants during the English program using their transcripts. The participants signed a consent form where they allowed us to use their students' codes to request both, the transcripts and the results of the Ileusco Test.

\subsection{Data Analysis}

After collecting data using the four research instruments, we proceeded to analyze it through the program Atlas.ti. Different sub-categories emerged from the two main categories established upfront in the research question, as evident in Figure 1.

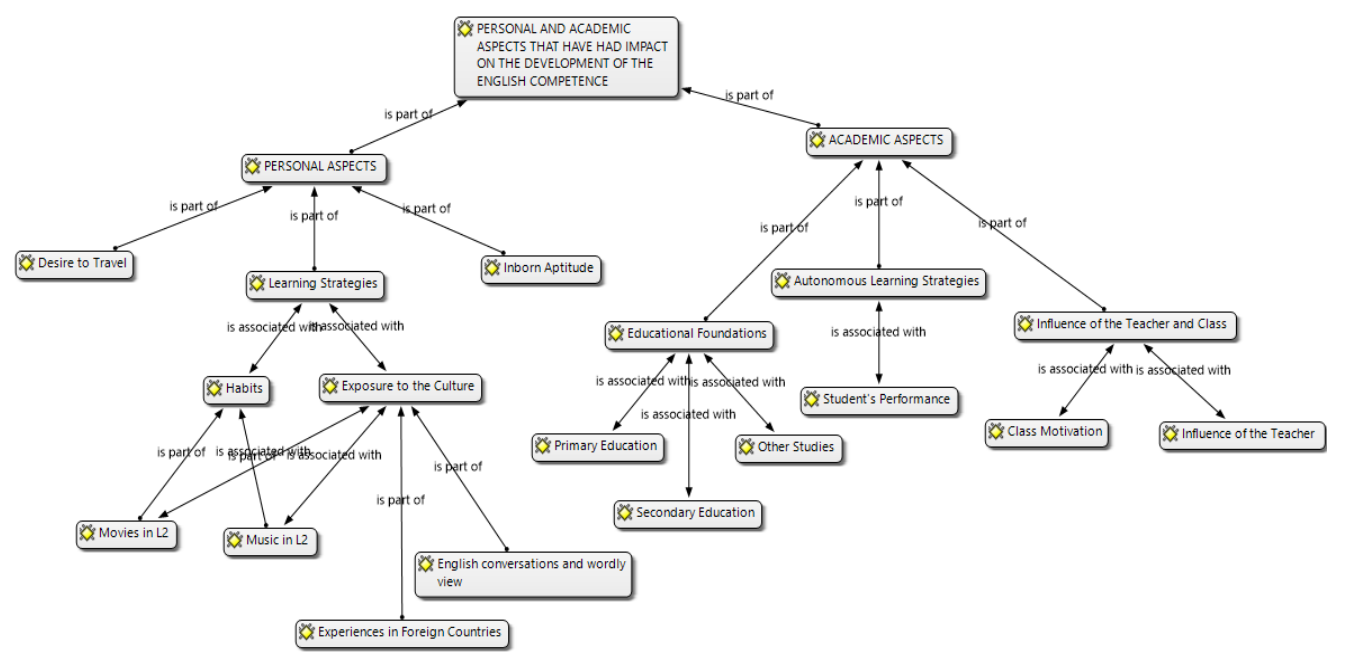

Figure 1. Categories and subcategories

The Personal Aspects are associated with actions that students performed and which somehow are out of the realms of the academic environment. It involves aspects related to learning actions they proactively implemented beyond the classroom.

Academic Aspects are related to L2 learning actions carried out by students within the academic realm. It includes educational background, students' performance in class as well as the influence of teachers.

\section{Results}

Some of the data obtained from the questionnaire will be presented through categories, graphs and brief qualitative and quantitative descriptions. Likewise, some of the information elicited from the interviews are displayed. The questions that have been selected for this section are those that bear a more direct relationship to the research questions.

\section{Questionnaire.}

\section{Educational foundation.}




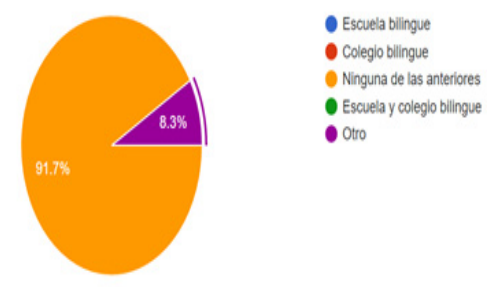

Graph 3.¿Estudiaste en escuela o colegio bilingüe?

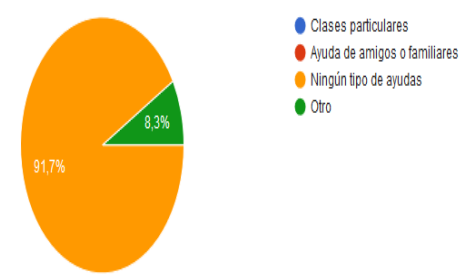

Graph 5.¿Has tenido clases particulares de inglés o ayuda de un familiar en tu formación escolar o universitaria?
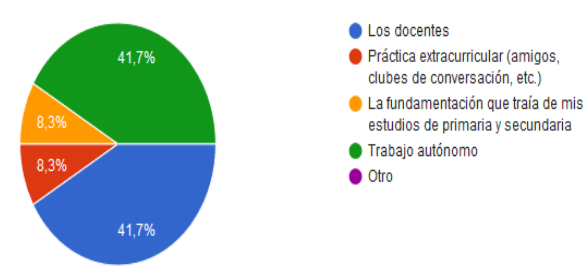

Graph 7. ¿Cuál crees que fue tu mayor influencia en tu proceso de aprendizaje de inglés durante tu carrera de pregrado?

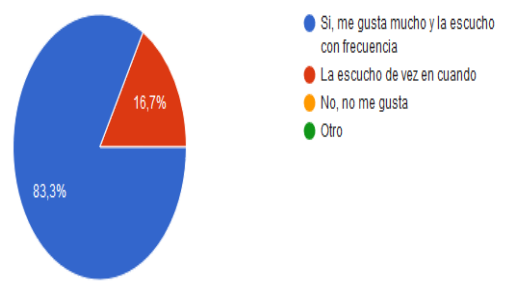

Graph 9.¿Te gusta la música en inglés?

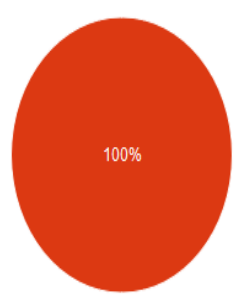

Si$$
\text { No }
$$

Graph 11. ¿Hay alguna persona en tu familia que hable inglés?

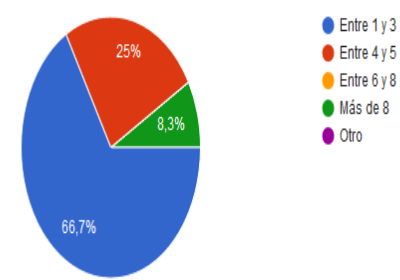

Graph 4.¿Cuántas horas de inglés a la semana tenías en tu escuela secundaria?

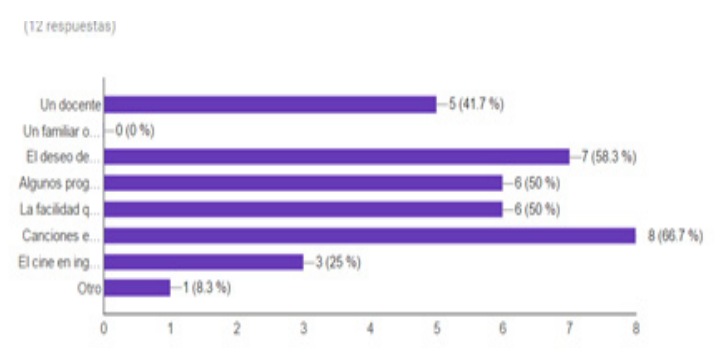

Graph 6.¿Qué crees que influyó en tu gusto por el inglés o en tu deseo por desempeñarte bien en el aprendizaje de esta lengua extranjera?

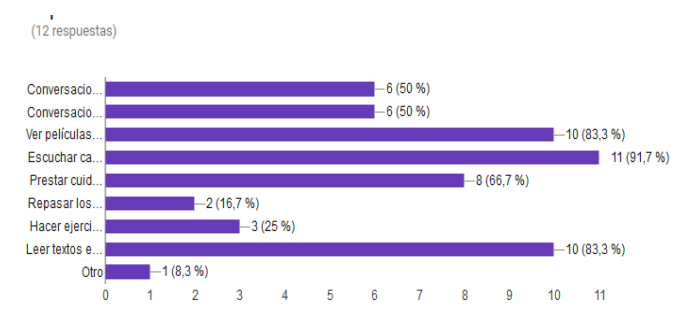

Graph 8. Marca las acciones que con mayor frecuencia realizabas durante tus estudios en la carrera de Lengua Extranjera

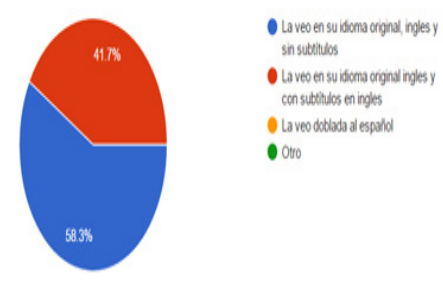

Graph $10 . ¿$ Cómo prefiere s ver las películas originalmente habladas en inglés?

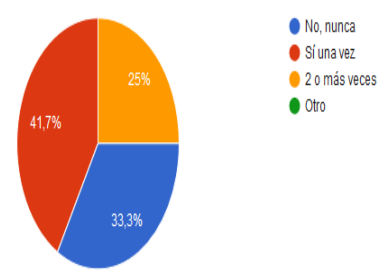

Graph 12.¿Alguna vez has viajado a un país donde se hable inglés como lengua oficial? 
The results show that $91.7 \%$ never studied in an elementary or secondary private school. Only one student, corresponding to $8.3 \%$ of the study, confirmed having studied elementary school in The United States of America.

Regarding secondary schools, $66.7 \%$ of the participants received 1 to 3 hours of English class per week, and $43.3 \%$ averaging more than 3 hours a week.

Furthermore, it was found that $75 \%$ of the participants never went to an English institute while attending either elementary or secondary school. 2 students (16.7\%) attended an English institute for more than a year. 1 student $(8.3 \%)$ took some form of online English courses.

The majority $(91.7 \%)$ of the participants never had help from friends or relatives nor took any kind of private English tutoring. The remaining $8.3 \%$ receiving tutorials at the university.

\subsection{Influence of the Teacher and Class Motivation}

According to the questionnaire, the teachers are mentioned as a great influence when it comes to the L2 learning process. $41.7 \%$ of the students claimed that an English Language teacher influenced their desire of acquiring an L2. Also, another $41.7 \%$ of the participants said the teachers were the biggest influence in the learning process during the program.

\subsection{Learning Strategies}

We identified the activities that helped students in the L2 learning process during the program. We had them select the activities they used to do more often during the time they were studying the Language Teacher Education program. According to the information gathered, $91 \%$ of the participants listened to music in $\mathrm{L} 2,83 \%$ watched movies in L2, another $83 \%$ read texts in L2, 66\% paid close attention in class and $50 \%$ of them had conversations with classmates and native speakers in English. The activities they did less were going over their notes from class and doing extra exercises on the internet.

\subsection{Exposure to the Target Language and Culture}

As part of the activities mentioned previously, we found the frequency with what the participants listened to music and watched movies in L2. The majority of students, corresponding to $83.3 \%$, listened to music frequently while $16.7 \%$ did it occasionally. About movies originally in L2, none of them watched movies dubbed to Spanish. We noted that 58.3\% watched them with no subtitles while $41.7 \%$ added subtitles in English.

It is important to note that none of the students who answered the questionnaire have English speaking relatives. However, traveling to an English speaking country has become more popular for students from the Language Teacher Education program. We identified that most of these students had had at least one experience in foreign countries. For instance, $41.7 \%$ of them have travelled one time and $25 \%$ had done it two or more times. However, $33.3 \%$ (4 students), have never been to an English-speaking country.

Conversations in L2 are significant in the process of learning an L2. All the participants sustained conversations with native English speakers while they were in the program; $41.7 \%$ had conversations with English native speakers very often; $33.3 \%$ did it sometimes and $25 \%$ only few times.

\subsection{Interviews}

The following information is a summarized report of the focus group interview where the participants answered questions related to academic and personal aspects that had an impact on the development of their English competence. The purpose of this group interviews was to expand on those aspects that students mentioned briefly whether in the questionnaire or in the individual interviews.

"Queremos que nos elaboren/describan un poco más sobre los aspectos o personas que influyeron en su gusto por el inglés." (We would like you to elaborate/describe a little more about the aspects or people that influenced your interest for English).

Most of the students agreed on the fact that the role of the teacher was key to develop that interest towards the language or else to dislike it. Another important aspect mentioned by them was English music. They all listened to English songs previous to the program or at the beginning and during the program. TV programs and movies were also important to change the perspective of the language. Some students mentioned that music as well as TV programs and movies in English created fascination for the target culture and the language itself. They also said that what we find in the media: internet, news, articles, magazines, and the like, influences students positively to learn English. 
“¿Por qué creen que hay estudiantes que repiten varias veces un nivel de inglés y no avanzan?” (Why do you think there are students who repeat an English level several times and cannot move on?)

According to the participants, there are a lot of factors such as work, time, economic issues, commitment, a natural ability and the support from the counselors. They mentioned that some students have to work while they are studying. Not all have the chance to focus only on studying due to the differences in their individual financial situations. Consequently, they can't dedicate enough time as they should. Another factor is the lack of commitment of some students with the academic process who despite having everything to do a great job, prefer not to do what they are asked to. Some students don't take the amount of autonomous work recommended by the faculty seriously.

On the other hand, participants added that although some students like English and dedicate time and effort, their results are not positive. According to them, in order to learn English there should be more than desire to learn it, there should be some sort of ability for it. Another reason could be that importance is not given to how necessary it is to learn a language. There is no a follow up of the students who are not doing so well academically so that the counselors can get a better idea of the reasons of their demotivation and weaknesses.

"Propongan una o varias estrategias que ustedes consideran fundamentales para afianzar el proceso de aprendizaje de inglés." (Suggest one or more strategies that you consider crucial to consolidate the English learning process).

Travelling and being in contact with the language, show students from the first semester all the opportunities that involve travelling and all the programs they can apply to. Demand the students to use the language for example, in the library or laboratory. These two places should have a rule where only English is allowed. Besides, counseling should be done by students from other semesters so they can get to know each other and interact more often.

The language should be practiced based on a topic of interest and freely. Teaching assistants should take advantage of how they catch people's attention. They motivate students to attend conversations clubs or tutorials. However, there should be native speakers that have an idea of pedagogy and are trained to teach since not all of them are teachers.

Technology can be used not only inside the class, but also outside. There are many tools that are not taken advantage of, the student today is centered on technology, and this could be a tool that can be included in the learning process. Also, there should be more opportunities to interchange with other programs inside the university and with other universities in the country (the total immersion is only one activity for the whole year and it is not enough). It would be an opportunity for the students to show what they have learnt in the program, and that could be used to increase their motivation and commitment in the academic process. The faculty should give academic permission so students can attend the symposiums held in the university. Not all professors excuse students when they miss classes to attend a conference even though they know these conferences are great opportunities to learn new approaches and strategies in the field of L2 teaching.

\section{Discussion}

After analyzing these main categories, we identified three subcategories belonging to Personal Aspects and three subcategories, which were part of Academic Aspects. This distribution is presented accordingly.

\subsection{Personal Aspects}

Inborn Aptitude: This sub category refers to the ability to learn the language. Some participants expressed awareness regarding their ability to learn English, which makes them sometimes different from their classmates. They acknowledged that learning and understanding English was easy for them even from an early stage of their life. They claimed that language learning does not happen in the same stage of life for every person. Not all students are able to acquire the language as easily as others, even after trying for a long time. The following comments support these statements:

Student 8: “...el profesor me pedía que les ayudara a mis compañeros con pronunciación, que con tareas y cosas así, entonces me daba cuenta que como que se me facilitaba aprender vocabulario todo eso."

Student 5: "cuando estaba el colegio se me quedaron las palabras fácilmente como que era fácil memorizarlas entonces eso como que influían ya no me daba tan duro en un parcial o un examen o si necesitaba algún trabajo era fácil entender entonces memorizar palabras."

Learning Actions: This sub category is associated with the actions that students performed in order to enhance their L2 proficiency. It is based on strategies that students used in their personal life to expose themselves to the 
L2 culture. These actions soon became part of their daily routines. Most students claimed having been influenced by movies and music in the $\mathrm{L} 2$, as well as by verbal interactions with native speakers.

Student 8: "el hecho de escuchar canciones todos los días, diferentes canciones todos los días, buscar la letra, buscar películas, de leer todo eso fue autónomo y nadie me dijo como venga lea, haga"

Student 6: "Cuando empecé a ver las películas completas en inglés y entendía y podía saber de qué hablaba la película muchos detalles me gustó mucho y seguí viéndolas y se convirtió como en el hábito de ver siempre las películas en inglés todas en inglés sin subtítulos ni nada."

Desire to Travel: We found the desire to travel as a very common aspect within the participants. It was one of the most motivating factors to learn the L2, not only while studying in the university program, but long before this stage. The participants mentioned how they wanted to go to other places in the world and assumed that it was easier to accomplish this goal if they first learned English. The following excerpts support these statements:

Student 6: "Yo si pensaba en salir del país y que sería chévere ir a un país que hablar otro idioma y pues como nadie del colegio sabía inglés entonces uno piensa en los países que habla inglés y pensaba como que ay que chévere que ir que otra experiencia...sería como una oportunidad más fácil pues uno ya saber hablar y se es más fácil uno comunicarse y viajar y salir."

Student 3: "Yo pienso que todos los que estudiamos inglés tenemos el deseo de ir a otros lados y de ejercer el idioma como en un contexto real"

\subsection{Academic Aspects}

Educational foundations: In this sub category, we found information related to primary and secondary education plus other studies the participants had done previous to or during the foreign language program. The majority of the participants went to public schools and had about two to three hours a week of English class and most of them did not attend extra English classes during their school years. It seems that the educational foundation of the participants was not as relevant for the L2 learning as other aspects found in this investigation. The following excerpts support these statements:

Student 10: "Yo estudié en un colegio público, entonces las horas eran súper escasas eran como dos horas a la semana ... Y a pesar de que eran como dos o tres horas a la semana con ella avanzamos bastante para ser un colegio público."

Student 1: "Estuve en uno de Huila habla inglés, si algo así, y era solo para los décimos y onces y yo estaba como en octavo..., fue muy bueno y en cualquier curso que durara así dos meses, pero no duraban seis meses, eran muy cortos, pero me metí."

Autonomous learning strategies: In this sub category, we placed information connected to the performance of the participants during class. It also involves preparation for class and the out-of-class time dedicated to reinforce aspects that required more attention. The actions mentioned by students are active participation in class, practice with online exercises, listening to audiobooks at night, participation in English clubs at school, and speaking practice with their peers out of class. The following excerpts support these statements:

Student 10: "Me gustaba participar bastante en clase todo el tiempo como que yo veía compañeros que no eran nada activos entonces yo aprovechaba eso... yo veía que los demás no participaban entonces siempre quise tomar la iniciativa porque veía que era la única oportunidad de practicar ingles...Hacía tareas, no se hacía los ejercicios, prestaba atención."

Student 1: "Si yo era muy cómo tipo Nerd, aplicada, era muy puntual me gusta mucho la puntualidad no me gustaba faltar a clases en inglés...ponía mucha atención... recibir asesorías... me iba estudiar más a la casa, coger el libro, hacer ejercicios extra, buscar en Internet cosas así."

Influence of the teacher and class motivation: In this section, participants mentioned how teachers became significant influence in their L2 learning process. We found that the methodology used by the teachers in the university and the way the classes were conducted stimulated the participants into liking English and wanting to be better at it. The learning process was more effective for the participants when their classes were dynamic, spontaneous and when the teacher showed dedication and interest towards the students. The following excerpts support these statements:

Student 11: "Pues... digamos que uno aprende inglés en la universidad simplemente porque los docentes obviamente lo saben, y porque los docentes son los que organizan las clases, organizan las secciones, y de esta manera es que uno aprende inglés." 
Student 6: "Los docentes tienen la habilidad de hacer que uno mejore mucho... yo tuve los últimos semestres unos profesores o sea cuarto y quinto sexto séptimo y octavo profesores muy buenos en su área pues eran dinámicos que traían cosas nuevas profesores que uno les preguntaba y sabían y si no sabían le llegaban con el dato y entonces cosas así muy interesantes entonces digamos que ellos fueron los que me tuvieron muy motivada siempre."

Thus, the aforementioned personal and academic factors have played a meaningful role in the L2 performance of the 12 sampled students throughout the EFL program both in their English courses and in the exit exam.

\section{Conclusions}

Not surprisingly, students' commitment and self-discipline kept the L2 learning process successfully running. And that commitment is perhaps the result of the different actions, wishes or goals that students bring with them from childhood or school years. Ryan and Deci (2000) conceive of self-determination not only as a capacity, but also a need which embodies "a basic, innate propensity to be self-determining that leads organisms to engage in interesting behaviors, which typically has the benefit of developing competencies, and of working toward a flexible accommodation with the social environment" (p. 68). Being always on time for classes, playing a very active role in class and being prepared with all the materials required for the class constitute positive actions in the learning of a second language. Undoubtedly, these correspond to qualities that help students succeed in any learning process. Also, students' desire to travel to an English-speaking country becomes an outstanding motivation for students to learn the language. Participants knew that traveling around the world would become easier when speaking a second language, especially if this was English. Consequently, developing communicative competence in English drew a path in their goal to travel abroad. They saw it as a door opener to personal or professional opportunities in a foreign country.

The role of teachers also impacts the motivation of students for learning English; the way the teachers prepared and organized their lessons made them either eager to learn more or be less interested in the subject. Some of the teachers and professors became role models from which they even learned strong values. As Herrera (2013) points out, the learning of a foreign language "can become overwhelming if teachers do not take the necessary steps to ease learners into the process" (p. 269).

It is indispensable for L2 learners to be resourceful and proactive by taking advantage of all sources they have at hand. According to the participants the following strategies and actions favor the L2 learning: reading not only the novels or stories assigned in class but also other texts that may enhance their exposure to the foreign language; resorting to downloadable audio versions of books and listening to them while resting; creating conversation clubs outside the university to exercise their speaking ability; gathering together to practice the language while carrying out daily activities such as cooking, shopping, travelling and playing sports; using digital applications to keep in contact with foreigners in the L2 and participating in online forums where L2 learners can discuss different topics of the educational field with people from all over the world; creating flashcards with vocabulary they are learning in school and playing with them in their free time; travelling to a country where the L2 is spoken officially happens to be effective actions for the development of the English competence as well and be surrounded by music, movies and series in the L2. They used to look for the lyrics of the English songs they listened to; they also watched movies and series in L2, sometimes with English subtitles to have a better idea of what the characters were saying; they could eventually watch the movies without subtitles. These students affirmed that music, movies and series in L2 complemented their second language learning process, not only by allowing them to be exposed to the language but also by being in contact with the cultural aspects involved in the process.

On the other hand, an inborn aptitude towards learning English seems to be a strong argument in this research, although further studies from the field of psychology, medicine and the like will reinforce this finding. Students are aware that there exists "something" that helps them learn the L2 easily or makes them strong learners.

Regarding educational foundations, even though pre-school and primary school seem to be fundamental stages for learners to build academic bases, higher education has been declared by the sample as the main educational stage to develop their high competence in English. They all came from public primary and secondary schools where they had very few hours of English classes, which mostly focused on learning vocabulary and grammar in a decontextualized manner. Despite today's emergence of schools with a strong emphasis on English language learning and bilingual schools (elementary and secondary schools), this study demonstrates that those students who cannot access such schools can still develop high proficiency upon accessing an ELT education program.

The present research study allows us to conclude that despite the high quality of a school curriculum, a language program or a teaching methodology, it is students' personal factors that mainly enhance their L2 proficiency. As 
previously stated, the personal factors entail students' autonomous learning initiatives such as listening to songs, watching series and movies in the L2, using technological applications to practice the language with people around the world, practicing the language in contexts beyond the classroom with classmates and friends, travelling abroad and being immersed in the English speaking country.

With regard to recommendations that can be provided out of the outcomes of this study, it is indispensable that either the learner, the parent or the teacher creates environments that expose the former to the target language and culture. Parents and teachers can contribute to this goal by having reading, audio or video materials at hand for children and teenagers to use. The contact with this type of materials may awake students' autonomous learning. Once they become more responsible learners, they can interact with other L2 native and non-native users in friendly circles, in more academic settings such as conversation clubs or through virtual means. The Internet also provides a plethora of activities and resources towards this goal. The experience of living in an English speaking country whether as a work or cultural exchange experience is undoubtedly of paramount benefit as well. Nonetheless, it does not constitute a sole guarantee for learning English, especially for academic purposes.

We expect that the different aforementioned factors, actions, and strategies draw a road for professors, parents and students to walk towards a more effective L2 teaching and learning process. Yet, we suggest further research that can validate and/or complement the findings yielded by the present study.

\section{References}

Cohen, A. D. (2011). Strategies in learning and using a second language (2nd Ed.). London: Routledge.

Creswell, J. W. (2009). Research design: Qualitative, quantitative, and mixed methods approaches (3rd ed.). Thousand Oaks, California: SAGE.

Dörnyei, Z. (2009). The L2 motivational self system. In Z. DOrnyei \& E. Ushioda (Eds.), Motivation, language identity and the L2 self. (pp. 9-42). Bristol, UK: Multilingual Matters.

Fraenkel, J. R., Wallen, N. E., \& Hyun, H. H. (2011). How to design and evaluate research in education (8th ed.). New York, NY: McGra-Hill.

García- Ros, R., Pérez-González, F., Martínez, T., \& Alfonso, V. (1998). Estrategias de aprendizaje y enseñanza del inglés como segunda lengua en contextos formales. Revista de Educación, 316, 257-269.

García, J. (2000). Entrenamiento en estrategias de aprendizaje de inglés como lengua extranjera en un contexto de aprendizaje combinado. Revista Nebrija de Lingüistica Aplicada a la Enseñanza de Lenguas, 8. Retrieved from https://www.nebrija.com/revista-linguistica/files/articulosPDF/articulo_5305ba376e77b.pdf

Gómez, E., \& Pérez, S. (2015). Chilean 12th graders' attitudes towards English as a foreign language. $\begin{array}{lllll}\text { Colombian Applied } & \text { Linguistics } & \text { Journal, } & \text { 17(2), }\end{array}$ https://doi.org/10.14483/udistrital.jour.calj.2015.2.a10

Hall, G. (2011). Exploring English Language Teaching: Language in Action. London: Routledge. https://doi.org/10.1093/elt/ccq075

Hardan, A. (2013). Language learning strategies: a general overview. Procedia - Social and Behavioral Sciences, 106, 1712-1726. https://doi.org/10.1016/j.sbspro.2013.12.194

Herrera, L. (2013). A five-feature language teaching proposal. Revista Lenguaje, 41(1), 263-281.

Loewen, S., \& Reinders, H. (2011). Key Concepts in Second Language Acquisition. Basingstoke: Palgrave Macmillan. https://doi.org/10.1007/978-0-230-34627-7

Ochoa, C., Cabrera, P., Quiñónez, A., Castillo, L., \& González, P. (2016). The effect of communicative activities on EFL learners' motivation: A case of students in the Amazon region of Ecuador. Colombian Applied Linguistics Journal, 18(2), 39-48. https://doi.org/10.14483/calj.v18n2.10018

Oxford, R. (2003). Language learning styles and strategies: An overview. GALA

Rojas, L., \& Artunduaga, M. (2014). percepciones de los estudiantes, profesores y egresados del programa de licenciatura en educación básica con énfasis en humanidades, lengua extranjera - ingles de la Universidad Surcolombiana sobre el fenómeno de repitencia de cursos de inglés asociado con el bajo nivel académico de estudiantes de los dos últimos semestres del programa. Informe de proyecto de investigación.

Ryan, R., \& Deci, E. (2000). Self-Determination theory and the facilitation of intrinsic motivation, social development, and well-being. American Psychologist, 55(1), 68-78. 
https://doi.org/10.1037/0003-066X.55.1.68

Saville-Troike, M. (2006). Introducing second language acquisition. Cambridge: Cambridge University Press. Retrieved from https://elt502ciu.wikispaces.com/file/view/Introducing+Second+Language+Acquisition.pdf

Tavallaei, M., \& Abu Talib, M. (2010). A general perspective on role of theory in qualitative research. Uluslararast Sosyal Arattrmalar Dergisi: The Journal of International Social Research, 3(11), 571-577.

Thomas, J., Nelson, J., \& Silverman, S. (2015). Research methods in physical activity (7th ed.). Champaing, US: Walsworth.

\section{Copyrights}

Copyright for this article is retained by the author(s), with first publication rights granted to the journal.

This is an open-access article distributed under the terms and conditions of the Creative Commons Attribution license (http://creativecommons.org/licenses/by/4.0/). 